\title{
The Political Usage of Religious and Non-religious Terms for Community in Medieval South Arabia: A Comparative Response to Gerda Heydemann's Chapter
}

\author{
Johann Heiss and Eirik Hovden
}

\section{Introduction}

This comparative response, or perhaps rather "reflection", will provide comparative cases to be seen in relation to Gerda Heydemann's article "People(s) of God? Biblical Exegesis and the Language of Community in Late Antique and Early Medieval Europe" in this volume. It will focus on several comparable community-related terms.

However, some fundamental epistemological considerations have first to be introduced in order to establish further comparability. A comparison of terms only, used in different regions, languages, and periods would not lead very far, since their meaning, potential, and significance are very much related to the way in which they are used by actors in specific contexts. An analysis based on one or more written "texts" certainly has some merits as a starting point and an orientation. However, it makes sense to take account of a wider range of primary and secondary context-related data, especially (but not only) considering community-related terms. The basic object of comparison must contain ideal and literal contents, in addition to a more or less "real", graspable historical context. Agency has to be included in the analysis, even though some of the terms used seem at the first glance to be remarkably stable across time and space, as if existing in their own right. A term itself has no agency, but the usage and belief in the term does. For us, the various community-related terms indicate the ability of people to (re)present, claim or resist visions of community, reflecting political aims, social realities or political-religious hierarchies. We do not intend to take an extreme instrumentalist position and claim that our study objects (people with agency and a particular usage of terms) did not "believe" in their community-related terms. Most of those using these terms may even have taken them for granted. However, most of our sources were written by highly educated individuals who chose to use specific terms deliberately and in specific ways, employing advanced conceptual apparatuses to

(C) JOHANN HEISS AND EIRIK HOVDEN, 2016 | DOI 10.1163/9789004315693_004

This is an open access chapter distributed under the terms of the Creative Commons Attribution- 
describe the social and ideal world around them, influenced by their particular interests or the interests of their patrons.

In the following, selected community-related terms will be analysed without taking extensive account of the usual modern political/religious divide. The separation between "religious" and "political"1 terms of communities is problematic on a theoretical/analytical level. However, there are certainly terms that are more frequently used in religious/theological discourse, while others refer to peoples and groups not directly involved in religious hierarchies, or not primarily related to religious discourse. In Arabic as in Latin and Greek, terms denoting groups (and many others) are taken from existing preChristian or pre-Islamic, often non-religious contexts (such as pre-Islamic poetry) and used in, and adapted to religious and other settings.

As is to be expected, our comparative cases are only apparently similar, at first glance resembling the European cases, which are used as a starting point for our response. The similarities but also the differences will be elaborated upon.

\section{The Term Umma/Umam}

Many meanings are ascribed to this word, among them one that many researchers would at first rightly refer to, which is "the Islamic community". 2 But there are other usages. In its most basic sense, its plural umam means "categories" or "peoples" as found in the Quran. ${ }^{3}$ The 1oth-century South-Arabian author al-Hamdānī uses the term this way. In the first part of his geographical work "Description of the Arab Peninsula" (Sifatjazirat al-Arab), he gives a thorough description of the inhabited world, where he uses, comments on and cites an Arabic translation of Ptolemy's (between ca. 100 and ${ }_{150}$ ) Tetrabiblos. ${ }^{4}$ The word

1 The research for this article was funded by the Austrian Science Fund (FWF): F42 Visions of Community. The concept of "ethnicity" used by Walter Pohl and Gerda Heydemann is partly different from its usage(s) in present day anthropology. We cannot go into the theoretical debates in depth here, but refer to the introduction to this volume.

2 Lewis, "Umma".

3 Quran 46:18: "It is [such as] these upon whom the sentence [of doom] will fall due, together with the [other sinful] communities [umam] of invisible beings and humans that have passed away before their time. Verily, they will be lost". This and the following quotations from the Quran are modified renderings of Asad's translation. See also the contribution by Lohlker in this volume.

4 Nowhere does al-Hamdānī give an indication that he read Greek, so he presumably used an Arabic translation of Ptolemy's work. 
$\varepsilon^{\prime \prime} \theta \nu \eta$ (ethne, plural of ethnos) used by Ptolemy is rendered as umam. ${ }^{5}$ Among other random examples, the same plural occurs in the description of the earth of al-Idrīsì (1099 or 1100-1165 or 66), who, writing around 1154 in Sicily, used the term umam to describe the "peoples" along the East African Coast or Turkic peoples in Central Asia. ${ }^{6}$ At least in the plural, the term umma could be used as a very general expression for "peoples", comparable to the Latin gens, but certainly without the etymological implications of common descent.

The most common meaning of the term in its singular is the invocation of the totality of the Muslim community, e.g. when the Yemeni imam al-Manșūr al-Qāsim b. 'Alī al-'Iyānī (reigned 999-1003) wrote in a letter of appointment to one of his governors: "The fuqah $\bar{a}$ ' [legal experts] are the specialists of religion and the wise men of the umma. ${ }^{7}$ However, this concept of "the Islamic community" is highly ideal, just like its notions of unity. By using the term umma, the imam addressed an ideally egalitarian community; yet at the same time implicitly saw himself at the top of the hierarchy. Around 200 years later, Imam 'Abd Allāh b. Hamza (reigned 1187-1217) did not hesitate to call his internal Yemeni Zaydi enemies unbelievers, ${ }^{8}$ thus in effect placing them outside the umma. The umma is therefore used as an idealized vision of a community. With this idea as a tool, internal, "heterodox" enemies could be excluded, with potentially severe consequences for them. The term umma is just one of many such all-encompassing, ideal religious community terms which can be appropriated by a self declared "orthodox" group and used against another group, with varying degrees of hostility, clearly depending on context. Umma can even carry a notion of "chosen people", e.g. in Quran 3:110: "You are the best of peoples" (kuntum khayra ummatin). But when in the Quran 2:213 the beginning of human society is alluded to, umma is used in a possibly not, or not only, religious way: "Mankind was once a single community" (kāna al-nāsu ummatan wāhidatan).

The terms "Muslims", "Islam" and "believers" can be used almost synonymously to umma. However, these terms can also be used in a less politico-legal way to describe and invoke an ideal moral community. Musallam al-Lahjī (died around 1150) wrote a large biographical collection of the members of the

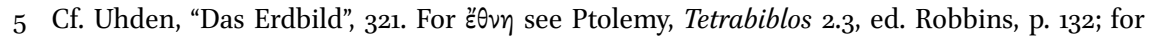
umam as translation of Ptolemy's text see al-Hamdānī, Sifatjazìrat al-'Arab, 39.

6 Al-Idrīsī, Opus geographicum, ed. Bombaci, $58 ; 849$.

7 Al-Ḥusayn b. Aḥmad, Sïrat al-Imām al-Manșūr, 114; in Imam al-Qāsim's description of the duties of the fuqahä, al-Ḥusayn b. Ahmad uses the word umma again three times, ibid., $114-15$.

8 Abū Firās b. Di'tham, al-Sïra al-sharīfa, 852-93. 
Muțarrifiyya (a Yemeni Zaydi branch). When he uses the term "Muslims", such as "the Muslims of the town of Shibām", ${ }^{9}$ he vaguely implies that not everyone there was "Muslim" in his eyes. Perhaps his claim should be interpreted as an appeal to the ideal moral individual as part of an equally ideal community of moral and pious men, something that is clearly the overall theme of his work (of course according to al-Lahjî's version of morality focusing on ideal notions, rather than using the term in strict inclusive/exclusive legal ways).

The use of umma as a community with clear borders, a common law, sharía, common activities, and its implied claim to universal validity corresponds in many respects to the term populus in a Christian sense, the populus Christianus, as shown by Heydemann. ${ }^{10}$ But especially in the plural, umam (like the gentes) can be defined as geographic units, without the notion of common descent as implied with gentes; in its singular, it frequently refers to the universal Muslim community, and in the plural to the many peoples which constitute it or to its pagan and heterodox opponents. The way gens and populus are used by Christian authors who also have political agendas is highly comparable. But the "meanings" of the terms must be seen in relation to the specific intention and context. Perhaps the clearest case Heydemann presents is that of Augustine in the Enarrationes in psalmos, where he defines the "people of God" (gens $D e i)$ as a universal community in his polemic against the competing vision of community of the Donatists. ${ }^{11}$

It would be outside the scope of this response to trace the development over time of some of these terms found in our sources from Yemen to match Heydemann's long durée of the usage of the gens/populus terms over three centuries, but it would be a rewarding task. Other terms used for communities, which are usually translated as "tribes", cannot be given a religious meaning (unlike the Latin terms for ethnic groups such as gens or natio). However, the fact that these terms are non-religious at first glance does not mean that they do not have relevance for religious actors of the medieval period, as will be demonstrated below.

\section{Tribes: Qabä'il and 'Ashä’ir}

The tribal people in South Arabia had their specific terms with which to express visions of their own communities or which were used by outsiders

9 Musallam al-Lahjīi, "Akhbār al-Zaydiyya", 253; cf. 248.

10 See Heydemann in this volume.

11 Ibid. 
to characterize and categorize them. Mainly, two different terms were used in South Arabia in the 1oth century which are usually translated as "tribe": qabilla (pl. qabā'il) and 'ashìra (pl. 'ashä'ir). Two other terms that are additionally but rarely used can only be mentioned here in passing: shac $b$ (pl. shu'üb), a SouthArabian word originally denoting sedentary tribes, ${ }^{12}$ and hayy (pl. ahya'). "Qabila" and "ashira" both occur in the Quran, qabāil only in the plural, together with shu'ūb, in Quran 49:13 (a passage popular with all genealogists):13

O mankind, indeed we have created you from male and female and made you qabāil and shu'üb so that you may know one another. Indeed, the most noble of you in the sight of God is the most righteous of you. Indeed, God is knowing and acquainted.

Ashir $a^{14}$ occurs three times in the Quran, and only in the singular, e.g. 9:24:

Say, if your fathers, your sons, your brothers, your wives, your 'ashïra, wealth which you have obtained, commerce wherein you fear decline, and dwellings with which you are pleased are more beloved to you than God and His Messenger and jihäd in His cause, then wait until God executes His command. And God does not guide the defiantly disobedient people.

Another passage is Quran 26:214: "And warn your closest 'ashïra". A comparison of the quotations shows that 'ashira in Quran 9:24 is mentioned in the context of the nearest consanguine and affinal relatives of a single person, the "you" who in this case is threatened by God. This group of relatives is obviously also meant with 'ashirataka al-aqrabina ("your closest kin-group"; Asad translated: "thy kinsfolk") in Quran 26:214. In the often cited verse Quran 49:13 no specific individuals are alluded to, but the qabāil and shu'üb denote at least groups whose members know each other, as the immediately following clause shows.

12 Al-Selwi, Jemenitische Wörter, 123-24; Beeston, "Shacb"; Beeston, "Some features of social structure in Saba".

13 The verb qabala in its third form (qābala) means "to meet, to be face to face with", see Chelhod, "Kabīla", 334-35, and in its sixth form (taqābala) "to face one another" (this form is taken by al-Hamdānī as explanation for qabīla, see al-Hamdānī, Kitāb al-iklīl 1, 6).

14 For the discussions regarding 'ashira see the entry in the Encyclopaedia of Islam by Lecerf, "Ashīra", 1:700, where he cited the lexicon Lisān al-'Arab: "The 'ashīra of a man is constituted by the nearest male offspring of his father". 
Groups like qabāil and shu'üb offer the people the possibility of getting to know one another.

In the following we want to describe these two terms, qabila and 'ashira, as they are used by two 1oth century authors in South Arabia. The first author is 'Alī b. Muḥammad b. 'Ubaydallāh al-'Abbāsī al-'Alawī, a follower of the first imam of Yemen, al-Hādī ilā al-Ḥaqq, who also wrote the latter's biography ("Sīrat al-Hādī ilā al-Ḥaqq Yahyaà b. al-Ḥusayn"). Al-'Abbāsī al-'Alawī was born around 880 near Medina in what is today Saudi-Arabia, and followed Imam al-Hādì (and his father, who fought at the imam's side) to the Yemen in the year 897. His North-Arabian descent (and at least partly that of his expected audience) becomes evident in some instances in his sira, when he has to explain South-Arabian words which he could not expect his hearers/readers to know (e.g. the word "mikhläf", 15 "region, province, district"). The second author is Abū Muḥammad al-Ḥasan al-Hamdānī, born possibly 893 near Sanaa, an opponent of the "immigrant" ashräf (members of the family of the Prophet) and also an opponent of the sons and successors of the first imam. In his genealogical and geographical works (Al-Iklül, Sifat jazirat al-Arab) he described landscapes and inhabitants of Yemen and their genealogies from a tribal point of view, as elaborated by Mahoney in this volume. As his name shows, he was a member of one of the large South-Arabian tribal federations, the Hamdān.

One difference between the two authors becomes immediately visible: in al-Hamdānī's work, qabīla is used far more often than 'ashïra, whereas in al-'Abbāsī al-'Alawī's the term qabïla occurs rarely, and 'ashïra is preferred. For al-'Abbāsī al-'Alawī, and in accordance with the Quranic usage, 'ashìra usually is the group of people immediately surrounding an individual, his or her close relatives. To give a few examples: he mentions the 'ashira of a person whose name he simply cites as al-Bahrī of Banū Bahrr; ${ }^{16}$ in another context he speaks of a certain Ḥunaysh, a man from a tribe called Wādi'a, and of a group (jamā'a $)^{17}$ of his 'ashìra; ${ }^{18}$ in another case he refers to the 'ashìra of al-Hādī, the first imam. ${ }^{19}$ But in other instances a slightly different use can be discovered. Al-'Abbāsī al-'Alawī once mentions the 'ashāìr of Hamdān, ${ }^{20}$ or the 'ashāir of

\footnotetext{
15 Al-'Abbāsī al-'Alawī, Sīrat al-Hādī, ed. Zakkār, 43; Al-Selwi, Jemenitische Wörter, 78.

16 Al-'Abbāsī al-'Alawī, Sìrat al-Hādī, ed. Zakkār, 80.

17 The term jamāa $a$ is a very common word for "group" with neither negative nor positive connotations.

18 Al-'Abbāsī al-'Alawī, Sīrat al-Hādī, ed. Zakkār, 89; see also 90.

19 Ibid., 156.

$20 \quad$ Ibid., 92.
} 
Banū Mi'mar. ${ }^{21}$ In such cases he talks of a large tribal group (the Banū Mi'mar) or even a whole confederation (Hamdān), which contains 'ashāir. Obviously with this usage he wanted to denote tribal subgroups, but avoided the usual terms given for them e.g. by al-Hamdānī (e.g. bayt or raht). Thus the author of the sira uses the word 'ashira in two ways: according to the Quranic usage as the group of people related by kinship to a special individual (usually in singular), or as a word for tribal subgroups (usually in plural).

In al-Hamdānì's texts 'ashìra is rarely used. Twice it occurs in Iklïl 8 (not a genealogical book) in tales about rather legendary persons of pre-Islamic times, where the author speaks of people possibly related through kinship to a certain individual. ${ }^{22}$ This use is similar to the Quranic one. But in al-Hamdānī's genealogical works (Iklïl 1, 2 and 10), where the word might be expected to occur, the term is not used. The focus on qabila results in a reverse picture. The word takes the place of 'ashìra of al-'Abbāsī al-'Alawī's second meaning: when he means tribal (sub)groups, al-Hamdānī uses qabìla, for example he speaks of qabāil of Hamdān, ${ }^{23}$ or of qabāंil of Qaḥțān living in Syria (al-Shām), making it clear that he is talking of all genealogically southern Arabs when he cites their common ancestor Qahțān. ${ }^{24}$ In yet another passage he declares that Ḥāshid the older (or the greater) and Bakil are the two important qabilatā (dual) of Hamdān; ${ }^{25}$ in the same book he denotes the offspring of (a group named) Alhān as the nearest qabïla to Hamdān. When speaking of the Yursam, al-Hamdānī describes the individual components of this genealogically incoherent group as qabä'il in his "Description of the Arab Peninsula", ${ }^{26}$ whereas in a similar attempt in $I k l \bar{l} l>$ the same groups, as components of Yursam, are designated as "bayt" (pl. "buyüt", "house"), ${ }^{27}$ thereby showing that the terms qabila and bayt are not entirely mutually distinguishable and have meanings partly congruent with each other. Consequently, with qabīla al-Hamdānī denoted a distinct tribal group, in many cases a subgroup of greater units or confederations like Hamdān.

In al-'Abbāsī al-'Alawī's biography of the first imam, the word qabila occurs only once (!), in iterated form: “....and Ibn Bisțām set out to ask Banū al-Ḥārith

\footnotetext{
21 Ibid., 134.

22 Al-Hamdānī, Iklīl 8, ed. al-Akwa', 191, 279.

23 Al-Hamdānī, Iklīl 2, ed. al-Akwa', 234; cf. al-'Abbāsī al-'Alawī, Sìrat al-Hādī, 92: 'ashā'ir of Hamdān.

24 Al-Hamdānī, Iklül 2, ed. al-Akwa', 242.

25 Al-Hamdānī, Iklïl ıo, ed. al-Khațīb, 28.

26 Al-Hamdānī, Sifat, ed. al-Akwa', 21.

27 Al-Hamdānī, Iklīl ı, ed. Löfgen, 118.
} 
for security, one qabïla after the other [qabillatan qabïlatan]". ${ }^{28}$ In this instance, the term qabila denotes subgroups of the confederation of Banū al-Hārith. Thus it has a function that the author usually characterizes by using 'ashira. For an explanation of this use of qabila in this special case one has to rely on guesswork. One possibility might be that, similarly to "bayt" and "qabila", the terms were not clearly defined and could in certain cases be used indiscriminately. Alternatively, the author al-'Abbāsī al-'Alawī might have reproduced an account from a South-Arabian source. Or he was using a fixed figure of speech-in his travelogue, the Andalusian Ibn Jubayr (540/1145-614/1217) described a procession in Mecca where people followed "qabïlatan qabïlatan wa-hăratan hāratan", "qabīla after qabïla and quarter after quarter". ${ }^{29}$

In conclusion an attempt will be made to explain the cause of the difference between the two authors where one uses almost exclusively the term 'ashira and the other only qabila. An obvious possibility would be to regard the different origin of the authors: one-al-Hamdānī - originated from South-Arabia, the other-al-'Abbāsī al-Alawī-from the north. Terminological differences between the two regions, together with the geographical location of the expected audience, might explain the disagreements. But there is another possible explanation: for an author writing, arguing and legitimizing largely in religious terms like al-'Abbāsī al-'Alawī in his biography, a large community like a qabila, with its power-related structures and claim to political influence and legitimacy, must have been seen as a threat to a religious community, an umma, under an imam who is striving to claim political (and religious) power for himself and his community. By contrast, perceiving an individual together with his or her nearest relatives as 'ashïra could rather be seen as something natural not per se standing in the way of an imam's claim to power. Thus al-'Abbāsī al-'Alawī could consciously have avoided the term qabila in order to undermine tribal visions of community and enhance the Islamic vision of it. On the other hand, al-Hamdānī, as an opponent of the descendants of the family of the prophet arriving from the north ('Alids, ashräf, ahl al-bayt), and as a member of one of the most influential South-Arabian tribal confederations of his time, could have done exactly the opposite: he may have preferred the use of the term qabila, thus emphasizing the political role the qabäil or tribes played in SouthArabian politics, thereby invoking a tribal vision of community where religion did not have the importance attributed to it by the imam and his followers, as also dealt with by Mahoney in this volume.

28 Al-'Abbāsī al-'Alawī, Sīrat al-Hādī, 358.

29 Ibn Jubayr, The Travels, ed. Wright, 130. 
One last remark should be added here: qabïla or tribe is not a term reserved exclusively for Arabs. When Arab authors described non-Arab people living far away from them, or when Arab travellers visited foreign non-Arab, non-Islamic lands, they sometimes discovered qabäill or tribes. Al-Idrīsì for instance described the Türgesh in Central Asia as a qabila of the Turkic peoples, who for him consist of several qabäill. ${ }^{30}$ Another example is provided by the famous traveller Ibn Bațūtata (703/1304-779/1377). When he traversed India, he passed through a town called Mālawa, named after a qabìla, which, as he states, "is one of the qabä'il of the Indians (al-Hunūd)". ${ }^{31}$ And finally, in South Arabia in Ayyubid times, al-'Arashānī (d. 1229), when he in his Kitāb al-ikhtișāṣ (book of preference) cited the origin of Amir 'Alam al-Dīn Wurdasār, twice mentions a group living in Yemen called qabīlat Shānkān, "one of the qabāil of the Kurds who belong to the Arabs, and it is maintained, to Nizār b. Ma'add b. 'Adnān". With his genealogical allusion he somewhat hesitantly ("it is maintained") ascribed a northern Arab genealogy to the Kurds, thus converting them into a kind of near "others". ${ }^{32}$ The Amir Wurdasār lives on in memory together with his qabīla, here called Shākān, because he left a building inscription on one of the minarets of the Great Mosque in Sanaa, which he erected in 1206/7.

As we have already mentioned, we wish to exercise caution in defining group terms as either religious or non-religious. Although the terms 'ashira and qabila are not religious per se, they can be used that way, as exemplified by al-'Abbāsī al-'Alawī's usage. In early medieval European history the development of "ethnic" groups has received much attention, while it seems problematic to export an exact notion of "ethnicity" to the Islamic and Yemeni context. Another community term, which interestingly is both related to "religion" and to the Europeanists' usage of "ethnic"33 and at the same time is at odds with the terms umma and qabïla described above, is the ashräf. We will come back to "ethnicity" after describing the ashräf.

\section{The Term Ashräf}

The ashräf (sing. sharīf) is the group that elsewhere in the Muslim world are called 'Alids ${ }^{34}$ and in later periods säda (sing. sayyid) in Yemen. The term is

\footnotetext{
$30 \quad$ Al-Idrīsī, Opus geographicum, 850 .

31 Ibn Bațțūța, Voyages, 4:28.

32 Al-'Arashānī, Kitāb al-ikhtișāṣ, 506 and 534.

33 For "ethnicity", see the introduction by Walter Pohl in this volume.

34 Lewis, "Alids"; Bernheimer, The 'Alids.
} 
linked to the well-known value "sharaf", meaning "honour" thus a good literal translation might be "nobility". The ashräfare most central actors in the sources in the medieval period from the Yemeni highlands. During the early medieval period, we see an influx of individuals and families from the male descent group of the family of the Prophet into various parts of Yemen. ${ }^{35}$ They often played an oppositional role in the Abbasid Empire, also inside Yemen, situating themselves in local tribal politics on the side of tribes opposing the Abbasids. In the highlands of Yemen they mainly adopted a Zaydi (Shi'i) creed, thus creating an Islamic counter-hegemony to the Abbasid agents there. The ashräf claimed to carry on the true religious orthodoxy and authority from the Prophet through the male blood line as individuals making up a group. This concept fitted well with the way communities at the time were conceived along genealogical lines. Most of the important ashräf families in Yemen, at least the leading families who laid claim to the Zaydi imamate, were descendants of al-Qāsim b. Ibrāhīm al-Rassī (d. 86o). ${ }^{36}$ It was first with Imam al-Hādī Yahyā b. al-Husayn (d. 911) that the tradition of Zaydism was introduced to Yemen in the years around AD 900 and since that time, his relatives and descendants have had a special grip on Zaydism and religious authority in the highlands of Yemen. ${ }^{37}$

The meaning of the term ashräf has seen significant change. At the beginning of the period under scrutiny (ca 900 $\mathrm{AD}$ ) they are usually referred to as 'Alids or Alawiss, also elsewhere in the Muslim world. ${ }^{38}$ Around 1000-1100 AD the term ashräf became common in highland Yemen, but we also see it used for the ashräf in Mecca and the ashrāf in al-Mikhlāf al-Sulaymānī in today's Saudi Arabia. "Ashräf" is a term they seem to have "occupied", as it was originally a local, tribal term referring to tribal "nobility". In around 1150 there are still a few instances where the term ashräf is used for tribal elites, but then always in a construct such as the "ashräf of Hamdān"; 39 "the tribal elites" or "nobility" of Hamdān, thus the appropriation of the term does not seem to be absolute. Perhaps one can also see a tendency that the term ashrä $f$ was used

35 One can talk about at least three distinct regions they settled in South Arabia: Hadramawt in the east where they today remain an important religious elite in local Shafi'i Sufism, in Lower Yemen and in the highlands of Yemen. Here we only deal with the latter and unlike the two first-mentioned regions, the 'Alids in the highlands usually claim to come from the Hasani branch, and a large majority of the important Zaydi elites claim descent from al-Q̄āsim b. Ibrāhīm al-Rassī (d. 86o).

36 Madelung, "al-Rassī, al-Ḳāsim b. Ibrāhīm".

37 For literature about the $s \bar{a} d a$, see Dresch, Tribes; Gochenour, "The Penetration".

38 Bernheimer, The 'Alids, "Introduction", 1-12.

39 Al-Lahjjī, "Akhbār al-Zaydiyya”, 30; Dresch, Tribes, 169, 191, n. 10. 
about specific ashräf clans such as the Qāsimi ashräf (al-ashräfal-qāsimiyyūn) based in Shahāra, while the ideal and religious status of all ashräf was rather invoked by the term ahlal-bayt, "the family of the House [of the Prophet]" or $\bar{a} l$ al-rasül, "the family of the Prophet", or similar. Some of the ashräf clans are also referred to in "tribal" terms like "Banū Hamza". At some point in the late medieval period, the ashrāf began to be called "sāda" (sing. sayyid), which is the term still used for them today as a community or social category in Yemen. ${ }^{40}$ Around $1000 \mathrm{AD}$ this was also originally a tribal term for tribal elites, much used by al-Hamdānī in his works, ${ }^{41}$ meaning "master" or "lord". Thus the community (insofar as one can claim they remain the same group over time) had several names, changing over time, of which ashräf is only one. It is problematic to use the term ashräf as the only term for this group in this rather short period when so many different terms were used for various phenomena related to them, and when other terms were used in other periods, but in this response, for the sake of simplification, they will be called ashräf.

The ashrāf were perceived to be northern Arabs and thus "outsiders" by intellectuals like al-Hamdānī. ${ }^{42}$ Their role and importance in the highlands of Yemen can be seen as one slowly increasing from the $9^{\text {th }}$ to the 14th century $\mathrm{AD}$, when we have reports of them immigrating to Yemen and becoming a group that increasingly held religious authority in the Zaydi sect there..$^{43}$ By constantly invoking their religious status as being different from non-ashrāf, they also marked a distance to the local tribal population as well as to local low-status groups. Over the course of the medieval period they became a distinct group in Yemeni society and they claimed a vision of community in the form of stratification towards a religious-political hierarchy with themselves at the top. They accepted that scholarly religious knowledge could also be transmitted among non-ashräf. However, the ashräf as a collective are portrayed as the bearers of religious knowledge and authority. In the version of Zaydism they upheld, the imamate, the ultimate leadership of the Muslim community, could only be held by a man of the ashräf. Unfortunately, most of our sources from the period were written by them, or by their local Yemeni supporters/ co-believers, which adds a decisive bias to the texts.

$40 \quad$ For the change towards using "sāda", see Zayd, Tayyārāt, 146.

41 Heiss, "Ein šayh ist ein šayh", 125-28.

42 See the article in this volume by Daniel Mahoney.

43 With certain setbacks, such as the opposition they faced from the Mutarrifiyya described by Hovden in this volume. For the growth of the ashrāf, see Gochenour, "Towards a Sociology". 
Contrary to the ideal notion of umma, the term ashräf is only applied to a specific group of believers, who in Zaydi (and Shi'i) law also have specific rights and duties relative to other Muslims. ${ }^{44}$ However, the term ashrä $f$ also includes certain notions of universality, since it refers back to "Islamic authority"; the existence of other groups with similar status is an impossibility. There cannot be other $a s h r a \bar{f}$ (although in practice there were certainly competing branches both inside and outside Yemen, there is only one ahl al-bayt).

To what extent can we use the term "ethnic" for such a group? They seem to straddle both the labels "religious" and "ethnic". Andre Gingrich has argued that "ethnicity" is a term ill fitted to describing the differences among the tribal groups in Yemen, since these are a majority in a society with a more or less shared language and culture. ${ }^{45}$ Indeed it is uncommon among anthropologists and historians to conceive of the tribal groups in Yemen as "ethnic" groups. Minority groups like the Jews, the Baniyans (Hindu traders) or the Abnä (alleged descendants of Persians) could more readily be seen as ethnic groups. During the time of colonial interest and until the 1980 os the social stratification of Yemeni society was a main focus for Western anthropologists, while later anthropologists have been more sceptical of reproducing this model, partly because it has such a strong bias in favour of those at the top. If we are to learn from contemporary ethnography, we can apply the same scepticism to the medieval period. The ashräf and the tribes are seen as two different communities partly alongside each other and partly arranged in a hierarchy, at least seen from the religious perspective of the $a s h r a \bar{f}$. Both groups were Arabs and spoke Arabic, which supposedly makes them the same ethnic group. However, they were also northern Arabs and southern Arabs respectively, with different dialects and cultural traits, which make them different. Both similarities and differences can be exaggerated and made significant, depending on the need to draw a line and the need to construct a difference.

If the ashräf invoked religion and were a "religiously" legitimated community, do they also fall outside the common usage of "ethnic"? The term "ethnoreligious", which could be used for an ethnic group that is also religiously distinct, is also not entirely fitting, because both the ashräf and the surrounding tribes are all Muslims. Arguably, the important point is not to answer whether or not the $a s h r a \bar{f}$ were an "ethnic" group, but rather to ask what we can

44 For a discussion of the conditions of the Zaydi imamate, see Zayd, Tayyārāt, 101-03, and the imamate in general; Madelung, "Imāma".

45 Gingrich, "Envisioning Medieval Communities in Asia". 
learn from theoretical debates on ethnicity and make use of this in the study of the ashräf. In the scope of this response this is something we can only mention in passing.

One obvious difference between ashräf and tribal visions of community is the vast written and intellectual culture of the Islamic sciences that the ashräf attached to, specialized in, and partly also monopolized. The ashrāf also had elaborate documentations of their genealogy all the way back to their forefather, the Prophet. Most tribal groups in Yemen or "ethnic" groups do not emphasize this documentation between individual and group in such a precise way, and therefore inclusion and exclusion is easier and more flexible. The ashräf could be quite strict in keeping their "purity". In this endeavour the ashräf are similar to European nobility and their ways of excluding other members of the allegedly same ethnic background. But when it comes to more general mechanisms of inclusion and exclusion, emphasizing differences in everyday practices vis-a-vis other groups, in clothing, ways of praying, marriage patterns etc., perhaps "ethnicity" can partly be seen.

The religious-political descent group is not so present in European medieval history, either for their elites or for the broader population. But, if we zoom out from Yemen, then we should not forget that the $a s h r a \bar{f}$ were a peripheral opposition phenomenon, a rather small minority in the wider Islamic world that indeed was also met with resistance locally. In Yemen the ashräf were met with opposition both from "below"46 and from other political and religious elites. One should not present the ideal of the ashräf as a "true" model of society in a historical sense, but rather as one vision of community among many, which was quite significant in the medieval period, and which inspired action and formed institutions. It was mainly an ideal useful for certain influential families among the ashrä $f$ in restricting ("religious") authority and the privileges combined with it to themselves. The position of the ashräf and the idea of the ahl al-bayt ("the house of the Prophet") is still controversial in Islam today, because it could be a logical breach in the idea that all believers are equal. Islamic reform movements have several times in history rejected and opposed this possibility of inequality.

The fact that genealogies of religious authority follow patrilineal bloodlines and not just "religious learning" is perhaps more common in Islam and Arabia than Europe. But then in the medieval period South Arabian society was

46 Perhaps the Muțarrifiyya can be seen an example where local Yemenis, tribal and lowstatus individuals used Zaydi doctrine, see Hovden in this volume. See also 'Alī Muhammad Zayd, Tayyārāt. 
already totally infused with ideas and discourses of patrilineal genealogy. Thus it is no wonder that this form of religious vision of community could therefore grow and exist within a highly tribalized society. One can perhaps ask if it was not because of the tribal visions of community in the highlands that the ashra $\bar{f}$ managed to persist for so long and to carve out a space in the otherwise universalist and egalitarian notions of "umma" and "Islam". The actors behind the Islamic and tribal visions of community could draw on each other's resources. This reminds us how important it is not to take the ashräf/tribe and religious/ political divide for granted, but rather to look at specific acts of community construction and develop models and representations of these.

\section{Conclusion}

The community-related terms that we have looked at more closely in this comparative analysis received their emotional, effective and adapted meanings from actors who used them for their own interests and strategies. This can explain the differences in usage among various authors and the development and change in the apparent meanings of the community-related terms over time. Unfortunately, unlike later periods in history, most of our sources were written by highly educated individuals, often in close proximity to political elites. It is therefore difficult to estimate which terms for community were common among a wider spectrum of the population; was it qabila or was it 'ashïra? Did commoners believe in and accept the ashräf's claims to superiority? If the term umma is "interpreted", it quickly leads us to highly idealized and complicated legal and theological theories that only experts could fully understand. The meaning of umma presumably changed rapidly between times of war and times of peace, the political tension adding momentum and potential to the term.

Perhaps the most useful exercise initiated by our comparison has been to learn more about the political situatedness of the authors of our sources. In this way we can also better tease out and separate the more taken-for-granted layers of the sources-layers that could be attributed to a general presence of certain visions of community-from those that are more propagandistic, written to serve a specific political purpose. In any case we must compare and contrast the different sources we have in order to see the dynamics and tensions between them and employ source criticism. A first step is content analysis of which terms appear in certain texts. But the second is to look for and theorize the agency behind the usages of these terms and to situate term, usage and agency in its historical context. 


\section{Bibliography}

'Alī b. Muḥammad b. 'Ubayd Allāh al-'Abbāsī al-'Alawī, Sīrat al-Hādī ilā al-Haqq Yahyā b. al-Ḥusayn [Biography of al-Hādī ilā al-Haqq Yahyā b. al-Ḥusayn], ed. Suhayl Zakkār (Beirut, 1981).

'Alī Muhammad Zayd, Tayyārāt mu'tazilat al-Yaman fì l-qarn al-sādis al-hïrī (Sanaa, 1997).

Alfred Felix Landon Beeston, "Sha'b", in Encyclopaedia of Islam, new ed., eds. Peri J. Bearman, Thierry Bianquis, Clifford Edmund Bosworth, Emeri J. van Donzel and Wolfhart P. Heinrichs (Leiden, 1960-2004), 9:150-52.

Alfred Felix Landon Beeston, "Some features of social structure in Saba", in Sources for the history of Arabia, 2 vols. (Riyadh, 1979), 2:115-23.

Al-'Arashānī, Sarī b. Fuḍayl, Nizāàm al-Dīn, Kitāb al-ikhtiṣāṣ [Book of preference], in al-Rāzī, Aḥmad b. 'Abdallāh b. Muḥammad, tārīkh madīnat Șan'ā', ed. Ḥusayn b. 'Abdallāh al-'Amrī, 3rd ed. (Beirut, Damascus, 1989), 491-724.

Ibn Batțūṭa, Abū 'Abdallāh Muhammad b. 'Abdallāh al-Lawātī al-Tanjī, Voyages d'Ibn Batoutah, 4 vols., eds. Charles Defrémery and Beniamino R. Sanguinetti (Paris, 1853-1858).

Theresa Bernheimer, The 'Alids: The First Family of Islam, 750-1200, (Edinburgh 2014). Joseph Chelhod, "Kabīla", in Encyclopaedia of Islam, new ed., eds. Peri J. Bearman, Thierry Bianquis, Clifford Edmund Bosworth, Emeri J. van Donzel and Wolfhart P. Heinrichs (Leiden, 1960-2004), 4:334-35.

Ibn Di'tham, Abū Firās, al-Sīra al-sharīfa al-Manșūriyya [The noble Manșūrī biography], ed. 'Abd al-Ghanī Maḥmūd 'Abd al-'Āṭī (Beirut, 1992).

Paul Dresch, Tribes, Government, and History in Yemen, (Oxford 1989).

Andre Gingrich, "Envisioning Medieval Communities in Asia: Remarks on Ethnicity, Tribalism and Faith", in Visions of Community in the Post-Roman World: The West, Byzantium and the Islamic World, 300-110o, eds. Walter Pohl, Clemens Gantner and Richard Payne (Farnham, Burlington, 2012), 29-41.

David Thomas Gochenour, “The Penetration of Zaydi Islam into Early Medieval Yemen”, (unpublished PhD diss., Harvard University, 1984).

David Thomas Gochenour, "Towards a Sociology of the Islamisation of Yemen", in Contemporary Yemen: Politics and Historical Background, ed. Brian R. Pridham (New York, 1984), 1-19.

Al-Hamdānī al-Ḥasan b. Aḥmad b. Ya'qūb, Abū Muḥammad, Kitāb al-iklīl al-juz’ alawwal (Book of the Crown, first part), ed. Oscar Löfgren (Leiden, 1954/65), cited as Iklīl 1 .

Al-Hamdānī al-Ḥasan b. Aḥmad b. Ya'qūb, Abū Muḥammad, Kitāb al-iklīlal-juz'al-thān̄ì [Book of the Crown, second part], ed. Muhammadb. 'Alīal-Akwa'al-Hiiwālī (Baghdad, 1980), cited as Iklïl 2. 
Al-Hamdānī al-Ḥasan b. Aḥmad b. Ya'qūb, Abū Muḥammad, Kitāb al-iklīl al-juz' al-thāmin [Book of the Crown, eighth part], ed. Muḥammad b. 'Alī al-Akwa' al-Ḥiwālì (Damascus, 1979), cited as Iklīl 8.

Al-Hamdānī al-Ḥasan b. Aḥmad b. Ya'qūb, Abū Muḥammad, Kitāa al-iklīl al-kitāb al- āshir [Book of the Crown, tenth part], ed. Muhibb al-Dīn al-Khațịb (Cairo, 1949), cited as Iklïl 10 .

Al-Hamdānī al-Ḥasan b. Aḥmad b. Ya'qūb, Abū Muḥammad, Sifat jazīrat al-'Arab [Description of the Arab peninsula], ed. Muhammad b. 'Alī al-Akwa' al-Ḥiwālī (Riyadh, 1974).

Johann Heiss, "Ein šayh ist ein šayh, aber was für ein Ding ist ein sayyid? Zur sozialen Entwicklung des Wortes sayyid", in Veränderung und Stabilität, Normen und Werte in islamischen Gesellschaften, ed. Johann Heiss, Veröffentlichungen zur Sozialanthropologie 7 (Vienna, 2005).

Al-Ḥusayn b. Aḥmad b. Yacqūb al-Hamdānī, Sìrat al-Imām al-Manșūr bi-Allāh al-Qāsim b. 'Alī al-Tyyānī [Biography of the Imām al-Manșūr bi-Allāh al-Qāsim b. 'Alī al-'Iyyānī], ed. al-Hibshī (Sanaa, 1996).

Al-Idrīsī, Muhammad b. Muhammad, Abū 'Abdallāh, Opus geographicum sive "Liber ad eorum delectationem qui terras peragrare studeant”, ed. Alessio Bombaci, Umberto Rizzitano et al. (Naples, Rome, 1970-1984).

Ibn Jubayr, Abū al-Ḥusayn Muḥammad b. Aḥmad b. Jubayr, al-Kinānī, al-Balansī, The Travels of Ibn Jubayr, ed. William Wright, 2nd ed., revised by Michael J. de Goeje (Leiden, London, 1907).

Al-Lahjī, Abū al-Ghamr Musallam b. Muḥammad b. Jacfar, "Akhbār al-Zaydiyya min ahl al-bayt 'alayhim al-salām wa-shī'atihim bi-al-Yaman" [Reports of the Zaydiyya consisting of people of the family of the prophet - peace be on them-and their Shi'a in Yemen], Jāmi`at Al-Imām Muhammad b. Sa‘ūd al-Islāmiyya, Riyadh, MS 2449.

Jean Lecerf, "Ashīra", in Encyclopaedia of Islam, new ed., eds. Peri J. Bearman, Thierry Bianquis, Clifford Edmund Bosworth, Emeri J. van Donzel and Wolfhart P. Heinrichs (Leiden, 1960-2004), 1:700.

Bernhard Lewis, "Umma”, in Encyclopaedia of Islam, new ed., eds. Peri J. Bearman, Thierry Bianquis, Clifford Edmund Bosworth, Emeri J. van Donzel and Wolfhart P. Heinrichs (Leiden, 1960), 10:859-63.

Bernhard Lewis, “Alids", in Encyclopaedia of Islam, new ed., eds. Peri J. Bearman, Thierry Bianquis, Clifford Edmund Bosworth, Emeri J. van Donzel and Wolfhart P. Heinrichs (Leiden, 1960), 1:401-03.

Wilferd Madelung, "Imāma”, in Encyclopaedia of Islam, new ed., eds. Peri Bearman, Thierry Bianquis, Clifford Edmund Bosworth, Emeri J. van Donzel and Wolfhart P. Heinrichs (Leiden, 1960), 1:1166. 
Wilferd Madelung, "al-Rassī, al-Ḳāsim b. Ibrāhīm b. Ismācil Ibrāhīm b. al-Ḥasan b. al-Ḥasan b. 'Alī b. Abī Ṭālib”, in Encyclopaedia of Islam, new ed., eds. Peri J. Bearman, Thierry Bianquis, Clifford Edmund Bosworth, Emeri J. van Donzel and Wolfhart P. Heinrichs (Leiden, 1960), 8:453-54.

Ptolemy, Tetrabiblos ed. Frank E. Robbins (Harvard, Mass., 1940).

Ibrahim Al-Selwi, Jemenitische Wörter in den Werken von al-Hamdānī und Našwān und ihre Parallelen in den semitischen Sprachen, (Berlin 1987).

Richard Uhden, "Das Erdbild in der Tetrabiblos des Ptolemaios", Philologus 88 N.F. 42 (1933), 302-25. 